\title{
An Overview of Forty Years Organotin Chemistry Developed at the Free Universities of Brussels ULB and VUB
}

\author{
Marcel Gielen \\ Université Libre de Bruxelles (ULB), Faculty of Sciences, Avenue F. D. Roosevelt, 50, B-1050 Brussels, Belgium \\ Vrije Universiteit Brussel (VUB), Faculty of Applied Sciences, Pleinlaan 2, B-1050 Brussels, Belgium
}

\begin{abstract}
Esta revisão cobre os principais eixos de pesquisa desenvolvidos nas Universidades Livres de Bruxelas entre 1961 e 2001. Primeiro, introduzimos os conceitos desenvolvidos no campo das reações de quebra das ligações carbono-estanho em compostos RR'R'R"'Sn usando reagentes E-N, obtendo-se R-E e R'R'R"'SnN, em solventes nucleofilos e não nucleofilos. A adição do nucleofilo ao íon metálico é necessária para permitir a quebra da ligação metal-carbono pelo eletrofilo. A reação pode ser caracterizada pela retenção da configuração do carbono quando um retentor cíclico é usado, ou pela inversão de configuração quando este retentor não é efetivo. A estéreo-seletividade de substituições nucleofilas bimoleculares em estanho é também discutida, bem como a (in)estabilidade de várias classes de tri-organo-estanho derivados. Finalmente, a atividade in vitro anti-tumoral promissora dos compostos di- e tri-organo-estanhos solúveis em água é referenciada.
\end{abstract}

This review covers the main axes of research developed at the Free Universities of Brussels between 1961 and 2001. This paper first introduces the concepts developed in the field of the cleavage reactions of carbon-tin bonds of RR'R"R'"Sn compounds by E-N reagents yielding R-E and R'R"R"'SnN in non-nucleophilic and nucleophilic solvents. The addition of a nucleophile at the metal atom is needed for allowing the electrophile to cleave the carbon-metal bond. The reaction can be characterized by retention of configuration at carbon when a cyclic constraint is imposed, or by inversion of configuration when such a constraint is not effective. The stereoselectivity at tin of bimolecular nucleophilic substitutions at tin is also discussed as well as the optical (in)stability of several classes of triorganotin derivatives. In the last part of this review, the promising in vitro antitumour activities of water-soluble di- and triorganotin compounds is covered.

Keywords: chiral organotin compounds, kinetics, SE2, stereochemistry, optical stability, antitumour activity

\section{1. $S_{E} 2$ Reactions at a Saturated Carbon Atom: Kinetics and Stereochemistry}

The investigation of the properties of organotin compounds started at the Free University of Brussels ULB (Université Libre de Bruxelles) in 1961 with the kinetic study of the bromo-, proto- and iododestannylation of tetraorganotin derivatives, in order to propose a mechanism for the bimolecular electrophilic substitution at a saturated $\mathrm{sp}^{3}$ hybridized carbon atom (Scheme 1). ${ }^{1,2}$

This reaction can be described as an $\mathrm{S}_{\mathrm{E}} 2$ reaction at a tetrahedrally substituted carbon as well as an $\mathrm{S}_{\mathrm{N}} 2$ reaction at a tetrahedrally substituted tin atom.

\footnotetext{
* e-mail: mgielen@vub.ac.be
}

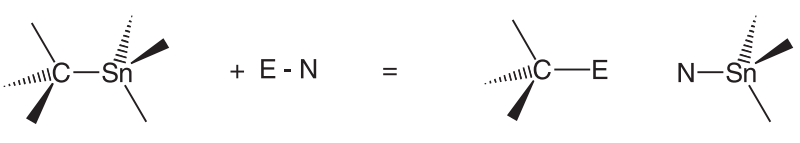

$\mathrm{E}-\mathrm{N}=\mathrm{Br}-\mathrm{Br}, \mathrm{H}-\mathrm{Cl}, \mathrm{I}-\mathrm{I}$

Scheme 1. Stoichiometry of the halo- or protodematallation at a saturated carbon atom.

A plausible general mechanism could be proposed that is compatible with all the kinetic and stereochemical data available. ${ }^{3-5}$

First, a nucleophilic addition to the metal atom needs to occur. Only afterwards can the substitution take place.

In a non-nucleophilic solvent, the nucleophilic part of E-N adds to tin, yielding an intermediate complex with a trigonal bipyramidally substituted tin atom (Scheme 2): 


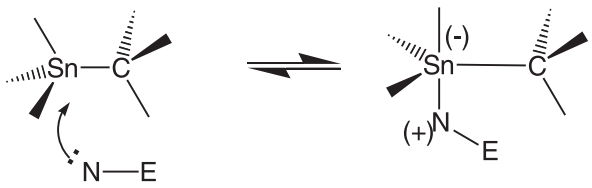

Scheme 2. First step of the cleavage of carbon-metal bonds: nucleophilic addition at tin.

In this intermediate, $\mathrm{E}$ is more electrophilic than in $\mathrm{E}-$ $\mathrm{N}$ because $\mathrm{E}$ is now bound to $\mathrm{N}^{(+)}$instead of to $\mathrm{N}$, and the carbon atoms of this intermediate complex bound to $\mathrm{Sn}^{(-)}$, more nucleophilic than those of the uncomplexed tetraalkyltin, bound to $\mathrm{Sn}$.

This intermediate complex can therefore in principle undergo three reactions.

First. An intramolecular reaction: the electrophilic E moiety can cleave an equatorial carbon-metal bond. This reaction is globally first order in the tetraalkyltin and first order in E-N and yields both reaction products (Scheme $3)$ :

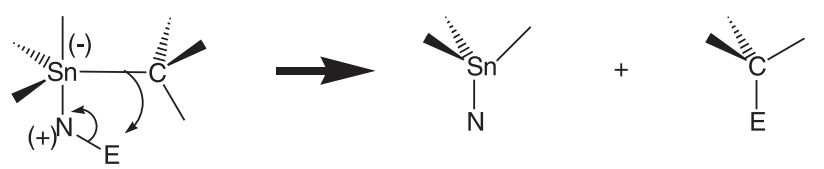

Scheme 3. Intramolecular reaction undergone by the intermediate complex: retention of configuration at $\mathrm{C}$ because of a cyclic constraint.

Because the transition state of this reaction contains a CENSn four-membered ring, the stereochemistry at carbon and at $\operatorname{tin}^{6}$ needs to be retention of configuration. The experimentally observed stereochemistry at carbon was indeed retention of configuration. The selectivity of the $\mathrm{C}$-Sn cleavage is quite low, all the alkyl-tin bonds being cleaved with similar rate constants.

Second. An intermolecular reaction with another tetraalkyltin molecule (Scheme 4):

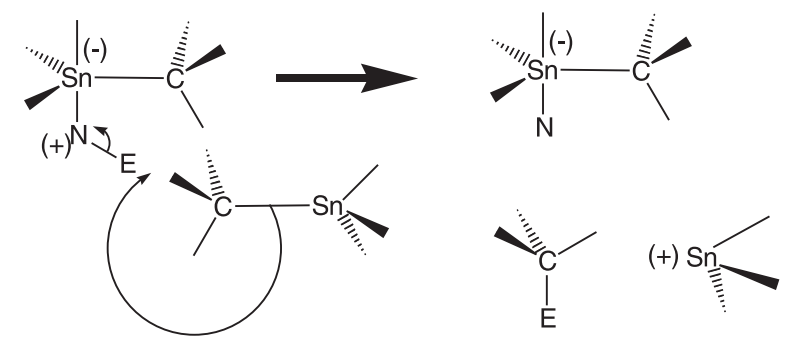

Scheme 4. Reaction of the intermediate complex with another tetraalkyltin molecule: inversion of configuration at $\mathrm{C}$.

The electrophilic E moiety of ${ }^{(+)} \mathrm{N}-\mathrm{E}$ is indeed so strong that it can cleave a C-Sn bond of another tetraalkyl molecule without needing any nucleophilic assistance. This reaction is globally first order in E-N and second order in the tetraalkyltin. This step yields only one of the reaction products, $\mathrm{E}-\mathrm{C} \equiv$ :

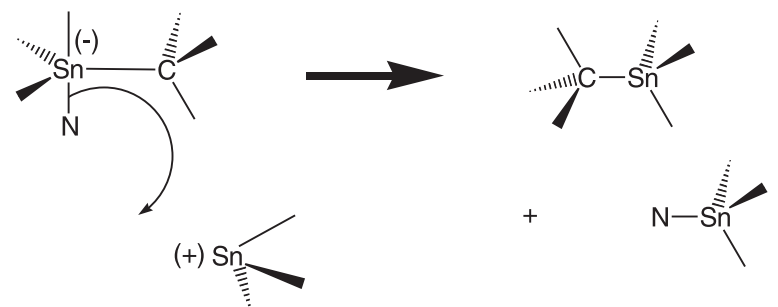

Scheme 5. A tetraalkyltin molecule is formed back in agreement with the stoichiometry.

The cation and anion formed in this step react with one another (Scheme 5), yielding back a tetraalkyltin and the other reaction products $\mathrm{N}-\mathrm{Sn} \equiv$.

Here, in principle, retention and inversion of configuration at carbon are both possible because there is no more cyclic constraint. Experimentally, it was shown that this intermolecular $\mathrm{S}_{\mathrm{E}} 2$ reaction occurs with inversion of configuration. The same conclusions were reached for the bromodemetallation of trialkylboron compounds. ${ }^{7}$

Third. An intermolecular reaction between the intermediate and the electrophilic moiety E of E-N (Scheme 6). This reaction is globally second order in E-N and first order in the tetraalkyltin.

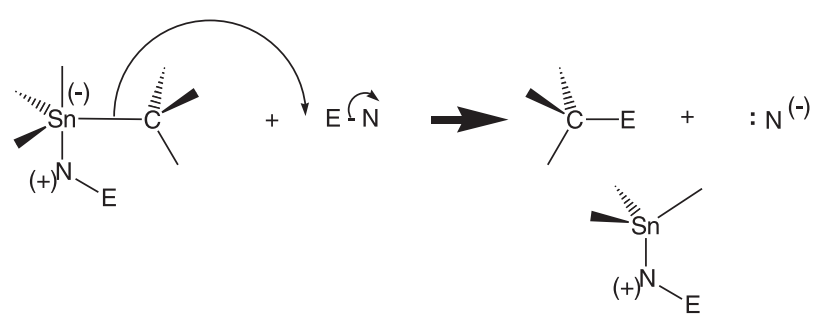

Scheme 6. Reaction of the intermediate with E-N: inversion of configuration at $\mathrm{C}$.

Here again, the cation and anion react with one another (Scheme 7). They yield E-N back:

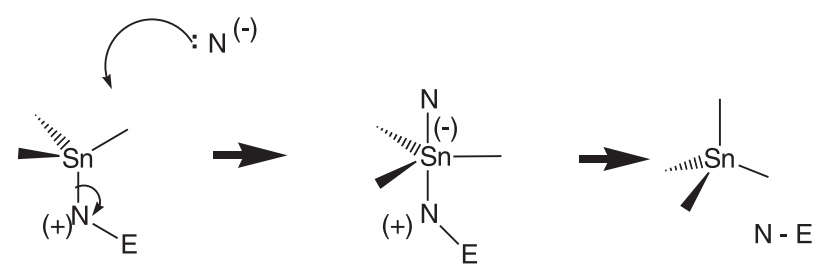

Scheme 7. Reaction of $\mathrm{N}^{(-)}$with the cation formed in the former step yielding E-N back, in agreement with the stoichiometry. 
The experimentally observed stereochemistry at $\mathrm{C}$ is again inversion of configuration.

The intermolecular steps are thus characterized by inversion of configuration at carbon. This seems to show that the preferred stereochemistry of $\mathrm{S}_{\mathrm{E}} 2$ reactions at a saturated carbon atom is inversion of configuration. Only if a cyclic transition state, implying a cyclic constraint, ${ }^{6}$ takes place, is the stereochemistry retention.

In a nucleophilic solvent, methanol for instance, the solvent first adds to tin (Scheme 8):

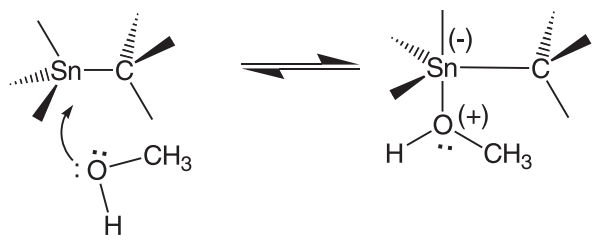

Scheme 8. Nucleophilic addition of methanol to the tin atom of the tetraalkyltin compound.

The only reaction that this intermediate complex seems to undergo is the intermolecular reaction with E-N (Scheme 9) with the cleavage of the apical carbon-tin bond, being weaker than equatorial carbon-tin bonds:

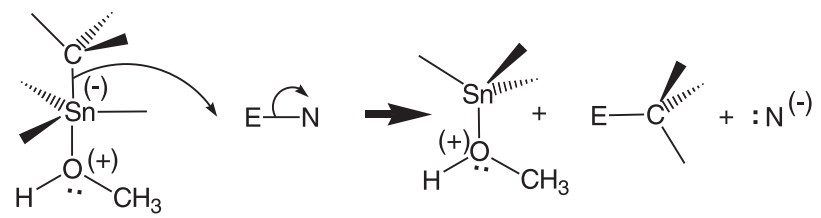

Scheme 9. Reaction of the intermediate with E-N: inversion of configuration at $\mathrm{C}$.

The reaction is globally first order in the tetraalkyltin, first order in E-N and first order in methanol. ${ }^{8}$ The stereochemistry of this reaction is inversion of configuration at carbon. Here again, there are no cyclic constraints, which confirms the fact that the preferred stereochemistry of $\mathrm{S}_{\mathrm{E}} 2$ reactions at a saturated carbon atom is inversion of configuration. Only if a cyclic transition state, implying a cyclic constraint ${ }^{6}$ is needed, is the stereochemistry retention.

The mercurideboronation in THF, a nucleophilic solvent, also occurs with inversion of configuration at carbon. $^{9}$

The selectivity in nucleophilic solvents is quite high, methyl-tin bond being cleaved much more rapidly than other alkyl-tin bonds.

The cation and the anion react with one another by a nucleophilic addition of $\mathrm{N}^{(-)}$to tin, yielding a solvated $\mathrm{N}-\mathrm{Sn} \equiv$ species:

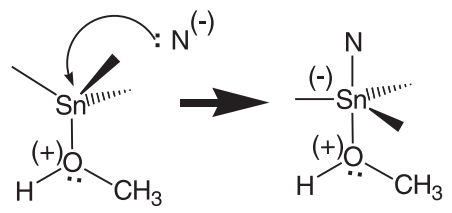

Scheme 10. Formation of a solvated trialkyltin bromide, halide or pseudo-halide.

\section{Stereochemistry at Tin of $S_{N} 2$ Reactions at a Tetrahedrally Substituted Tin Atom}

In order to study the stereochemistry at tin, first racemic ${ }^{10-14}$ and then chiral ${ }^{15,16}$ organotin compounds need to be synthesized.

By taking into account the fact that the selectivity of $\mathrm{C}-\mathrm{Sn}$ cleavage reactions by electrophiles is high in nucleophilic solvents whereas it is very low in nonnucleophilic ones, ${ }^{12}$ the first racemic tetraalkyltin compound, methylethylisopropylcyclohexyltin, was synthesized (Scheme 11): ${ }^{10}$

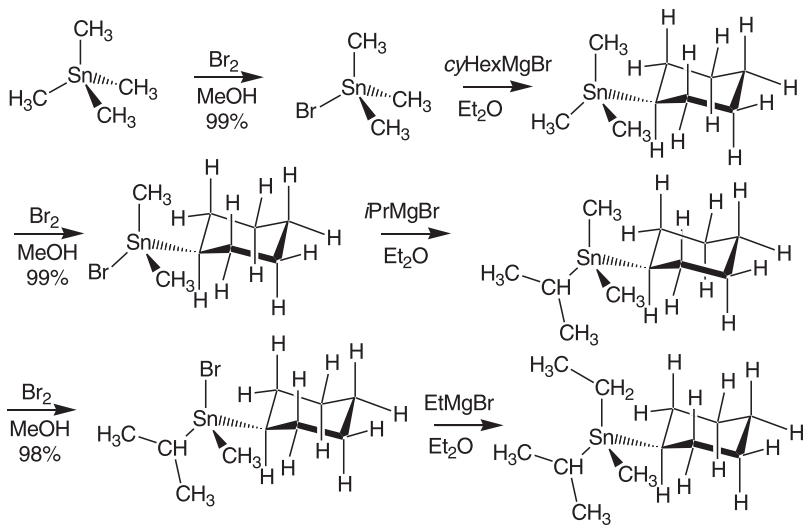

Scheme 11. Synthesis of the first racemic pure tetraalkytlin.

The reaction of this asymmetrically substituted tetraalkyltin with bromine in chlorobenzene, a poorly nucleophilic solvent, yields similar amounts of the four expectable alkyl bromides whereas the same reaction in the nucleophilic solvent methanol affords methyl bromide and pure ethylisopropylcyclohexyltin bromide that, by reacting with any other alkylmagnesium bromide, yields alkylethylisopropylcyclohexyltins containing no methyl group linked to tin.

The syntheses of other racemic tetraorganotin compounds were successfully achieved starting for instance from tetraphenyltin or tetrakis ( $p$-methoxyphenyl)tin. ${ }^{12-14}$

Of course, now, optically pure tetraorganotin compounds containing only a chiral tin center can be 
synthesized in order to study the stereochemistry at tin. This has been achieved by preparing first racemic methyl $(p-$ methoxyphenyl)-1-naphthyltin hydride starting from tetra( $p$-methoxyphenyl)tin and by reacting then that intermediate with (-)menthyl acrylate (Scheme 12): ${ }^{15}$<smiles>COc1ccc([Sn](C)(C)c2cccc3ccccc23)cc1</smiles><smiles>COc1ccc([AsH](C)(C)C)cc1</smiles><smiles>COc1ccc([Si](C)(CC(=O)O[C@H]2CC(C)CC[C@@H]2C(C)C)c2cccc3ccccc23)cc1</smiles><smiles>C=CC(=O)OC1=C(C(C)C)CCC(C)C1</smiles>

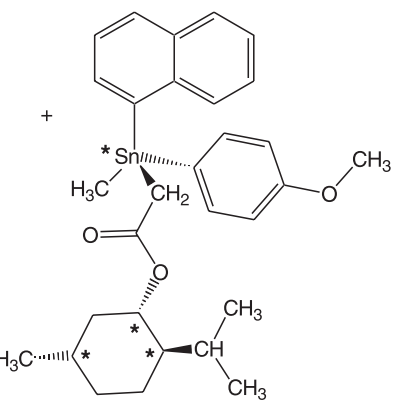

Scheme 12. Addition of methyl( $p$-methoxyphenyl)-1-naphthyltin hydride to (-)-menthyl acrylate yielding two diatereoisomers.

The two diastereoisomers formed could be separated by fractional recrystallizations. Each of them was then reacted with an excess of methylmagnesium iodide and yielded the expected tertiary alcohol in which tin was the only chiral center (Scheme 13). ${ }^{15-18}$

These two enantiomers have of course the same $\left|\alpha_{\mathrm{D}}\right|$ but different signs, as expected. After several years, these $\alpha_{\mathrm{D}}$ values did not change, evidencing the optical stability of tetraorganotin compounds.

The optical stability of tetraorganotin compounds has also been determined differently: racemic tetraorganotins containing diastereotopic groups like methylphenylneophyltrityltin were synthesized and NMR spectroscopy also showed that this compound is optically stable within the NMR time scale.

The enantiomers of a racemic mixture of the two enantiomeric methylphenylneophyltrityltins could be separated on a chiral microcrystalline cellulose triacetate chromatography column. ${ }^{19,20}$ Their optical activity remained unchanged for years.

This optically stable methylphenylneophyltrityltin was

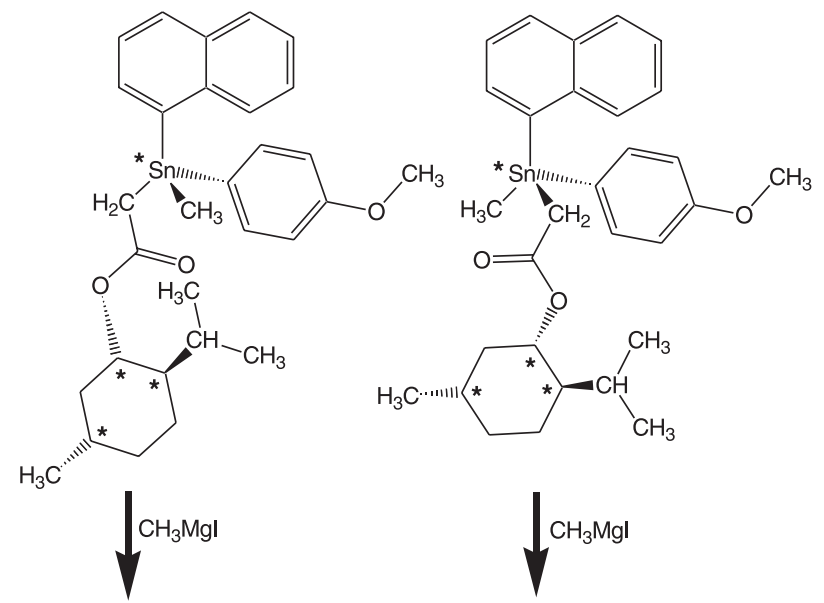<smiles>COc1ccc([Sn](C)(CC(C)(C)O)c2cccc3ccccc23)cc1</smiles>

Scheme 13. Reactions of the two diastereoisomers with methylmagnesium iodide yielding, in two separate reactions, the two enantiomeric tetraorganotin compounds containing tin as the only chiral center.

reacted with bromine in methanol/chlorobenzene to yield the corresponding triorganotin halide (Scheme 14):

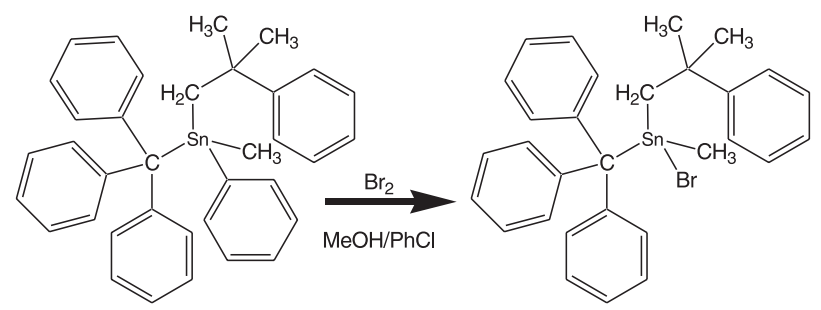

Scheme 14. Bromodemetallation of methylphenylneophyltrityltin in methamol/chlorobenzene yielding an optically stable triorganotin halide (within the NMR time scale).

Proton NMR showed that, even in the presence of $1 \mathrm{~mol} \mathrm{~L}^{-1}$ DMSO, a very nucleophilic solvent, the methyl and methylene protons remained anisochronous $(\Delta v=$ $12 \mathrm{~Hz}$ and $9.4 \mathrm{~Hz}$, respectively).

In fact, unfortumately, not all the triorganotin halides are optically stable, even within the NMR time scale. Only sterically hindered ones are. ${ }^{21}$ Methylphenylneophyltin chloride racemizes in the presence of pyridine. The second order in pyridine was proven by determining the rates of coalescence by NMR at 60,100 and $270 \mathrm{MHz} .{ }^{22}$ The intermediate responsible for the racemization is either an 
achiral bipyramidal or octahedral species with two pyridine moieties in apical positions (Scheme 15). ${ }^{22}$

a)<smiles>[Y][Sn]([R7])([PH])[NH2+][NH3+]</smiles>

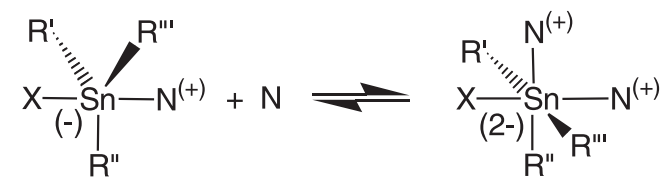

or b)

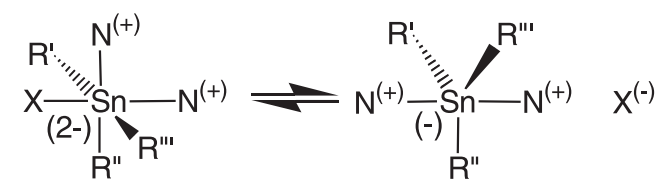

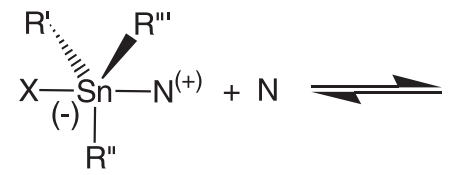

$$
\mathrm{N}(+)=\left.\right|_{\mathrm{R}^{\prime \prime}} ^{\mathrm{R} n} \mathrm{R}^{\prime \prime \prime}
$$

Scheme 15. Possible mechanisms for the racemization of a chiral triorganotin halide in the presence of traces of nucleophile.

Triorganotin phenoxides are, like triorganotin halides, configurationally unstable, as shown by Taddei. ${ }^{23}$

It was interesting to investigate which other triorganotin compounds are optically stable.

Chiral triorganotin hydrides were synthesized by reacting the corresponding chlorides at $-50^{\circ}$ with (-)-menthoxide and by reducing with $\mathrm{LiAlH}_{4}$ the triorganotin menthoxides formed.

Optically active triorganotin hydrides were also synthesized by reduction of a racemic triorganotin halide with a chiral aluminium hydride (Scheme 16): ${ }^{24-26}$

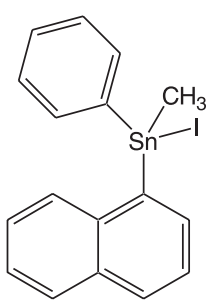

racemic

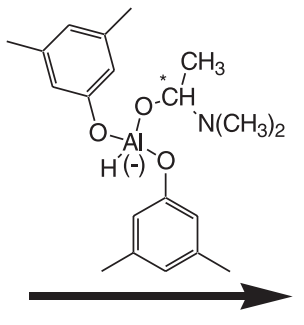

$[\alpha]_{365}^{30^{\circ}}+2.0$

optical purity unknown
Scheme 16. Synthesis of an optically active triorganotin hydride by reduction of the corresponding triorganotin iodide with a chiral reduction agent.

The triorganotin hydride obtained was found optically stable in the presence of hydroquinone. It racemises slowly in diethyl ether or in benzene and more rapidly in the presence of AIBN. Triorganotin hydrides are known to react with radicals, being then transformed into the triorganotin radical that is racemizing. It racemizes even more easily in the presence of methanol by a mechanism maybe similar to the one invoked to explain the racemization of triorganotin halides.

Optically active triorganotin hydrides react with $\mathrm{LiAlD}_{4}$ or $\mathrm{R}_{3} \mathrm{SnD}$ yielding the corresponding triorganotin deuterides with retention of configuration and some racemization.

Optically active neophylphenyltrityltin hydride was converted into optically active methylneophylphenyltrityltin by reaction with diazomethane, and into an optically active tetraorganotin compound by addition to the central $\mathrm{C}=\mathrm{C}$ bond of bifluorenylidene.

Triorganotin menthoxides give, by reacting with triphenylgermyl lithium, the corresponding optically active triphenylgermyltriorganotin (optical purity also unknown). ${ }^{27}$ Similarly, optically active methylneophylphenyltin hydride is converted into the corresponding optically active hexaorganoditin by reaction with $\mathrm{Pd} / \mathrm{C}$ and elimination of $\mathrm{H}_{2}$.

Triorganostannylamines, -phosphines and -arsines are also configurationally stable within the NMR time scale. ${ }^{28}$

Triorganotin-transition metal complexes like $\left(\mathrm{C}_{6} \mathrm{H}_{5}\right)\left(\mathrm{CH}_{3}\right)_{2} \mathrm{Sn}-\mathrm{Fe}\left(\mathrm{h}^{5}-\mathrm{C}_{5} \mathrm{H}_{5}\right)(\mathrm{CO}) \mathrm{P}\left(\mathrm{C}_{6} \mathrm{H}_{5}\right)_{3}$ or $\left(\mathrm{CH}_{3}\left(\mathrm{C}_{6} \mathrm{H}_{5}\right)\left(\mathrm{CH}_{3}\left(\mathrm{C}_{6} \mathrm{H}_{5}\right) \mathrm{CH}-\mathrm{CH}_{2}\right) \mathrm{SnML}_{\mathrm{n}}\left(\mathrm{ML}_{\mathrm{n}}=\mathrm{Fe}(\mathrm{CO})_{2}\right.\right.$, $\mathrm{Mn}(\mathrm{CO})_{5}$ or $\mathrm{Co}(\mathrm{CO})_{3} \mathrm{P}\left(\mathrm{C}_{6} \mathrm{H}_{5}\right)_{3}$ are configurationally stable within the NMR time scale. ${ }^{29-33}$ This is also the case for methylneophylphenylstannylcyclopentadienyltricarbonylmanganese.

Chiral triorganostannyltransition metal complexes have been synthesized. For instance, methylnaphthylphenylstannyltetracarbonyl(diphenyl-N-methyl-N-(S)-1phenylethyl-aminophosphine)manganese could be prepared by two different routes and the presence of an optically pure (S) ligand at manganese allowed to separate the two diastereoisomers by fractional recrystallizations.

\section{In Vitro Antitumour Activities of Organotin Carboxylates Containing the Polyoxaalkyl Moiety}

In our laboratory, many series of organotin compounds were synthesized, characterized and screened in vitro and in vivo. ${ }^{34}$ Almost all were found more active than cisplatin and some were even comparably in vitro active as doxorubicin, both being clinically used drugs (see for instance ${ }^{39}$ ).

Only the very last results obtained in our laboratory will be summarized here because recently a review paper 
has appeared in which all our papers related to this field are described. ${ }^{34}$

The synthesis and in vitro screening of even more water-soluble organotin compounds, containing a polyoxaalkyl moiety linked to tin either by a carbon-tin or by a carbon-oxygen bond (Schemes 17 and 18), ${ }^{35-38}$ was one of our latest developments in this area. Many of these<smiles></smiles>

$1 \mathrm{R}^{\prime}=\mathrm{C}_{6} \mathrm{H}_{5}, \mathrm{R}=\mathrm{CH}_{3} \mathrm{OCH}_{2} \mathrm{CH}_{2} \mathrm{OCH}_{2}$

$5 \mathrm{R}^{\prime}=\mathrm{C}_{6} \mathrm{H}_{5}, \mathrm{R}=\mathrm{CH}_{3} \mathrm{O}\left(\mathrm{CH}_{2} \mathrm{CH}_{2} \mathrm{O}\right)_{2} \mathrm{CH}_{2}$

$2 \mathrm{R}^{\prime}=\mathrm{n}-\mathrm{C}_{4} \mathrm{H}_{9}, \mathrm{R}=\mathrm{CH}_{3} \mathrm{OCH}_{2} \mathrm{CH}_{2} \mathrm{OCH}_{2}$

$6 \mathrm{R}^{\prime}=\mathrm{Cn}_{4} \mathrm{H}_{9}, \mathrm{R}=\mathrm{CH}_{3} \mathrm{O}\left(\mathrm{CH}_{2} \mathrm{CH}_{2} \mathrm{O}\right)_{2} \mathrm{CH}_{2}$

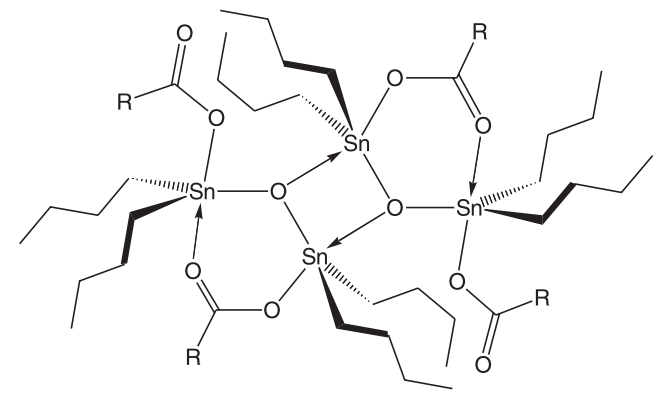

$4 \mathrm{R}=\mathrm{CH}_{3} \mathrm{OCH}_{2} \mathrm{CH}_{2} \mathrm{OCH}_{2}$

$8 \mathrm{R}=\mathrm{CH}_{3} \mathrm{O}\left(\mathrm{CH}_{2} \mathrm{CH}_{2} \mathrm{O}\right)_{2} \mathrm{CH}_{2}$

Scheme 17. Organotin polyoxaalkylcarboxylates screened in vitro against seven human tumour cell lines.

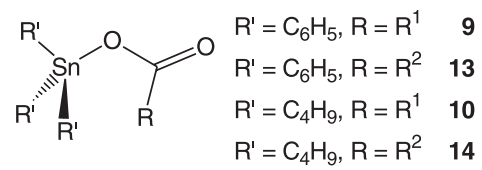

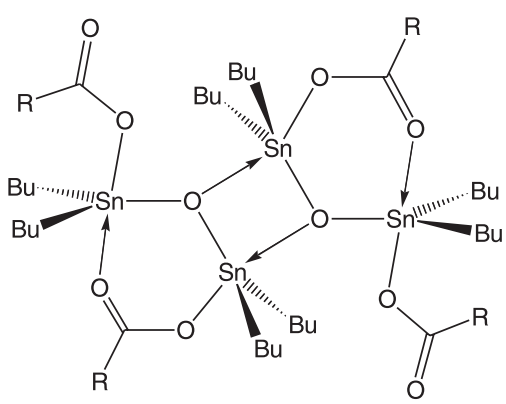<smiles>[R7]COCCOCCOc1cc(C)ccc1OCCOCCOCCOCCOCCOCC</smiles>

Scheme 18. Benzocrowncarboxylates screened in vitro against seven human tumour cell lines. compounds exhibit very high in vitro antitumour activities against the seven human cell lines tested.

The crystal structures of two of these compounds are shown in Scheme 19.
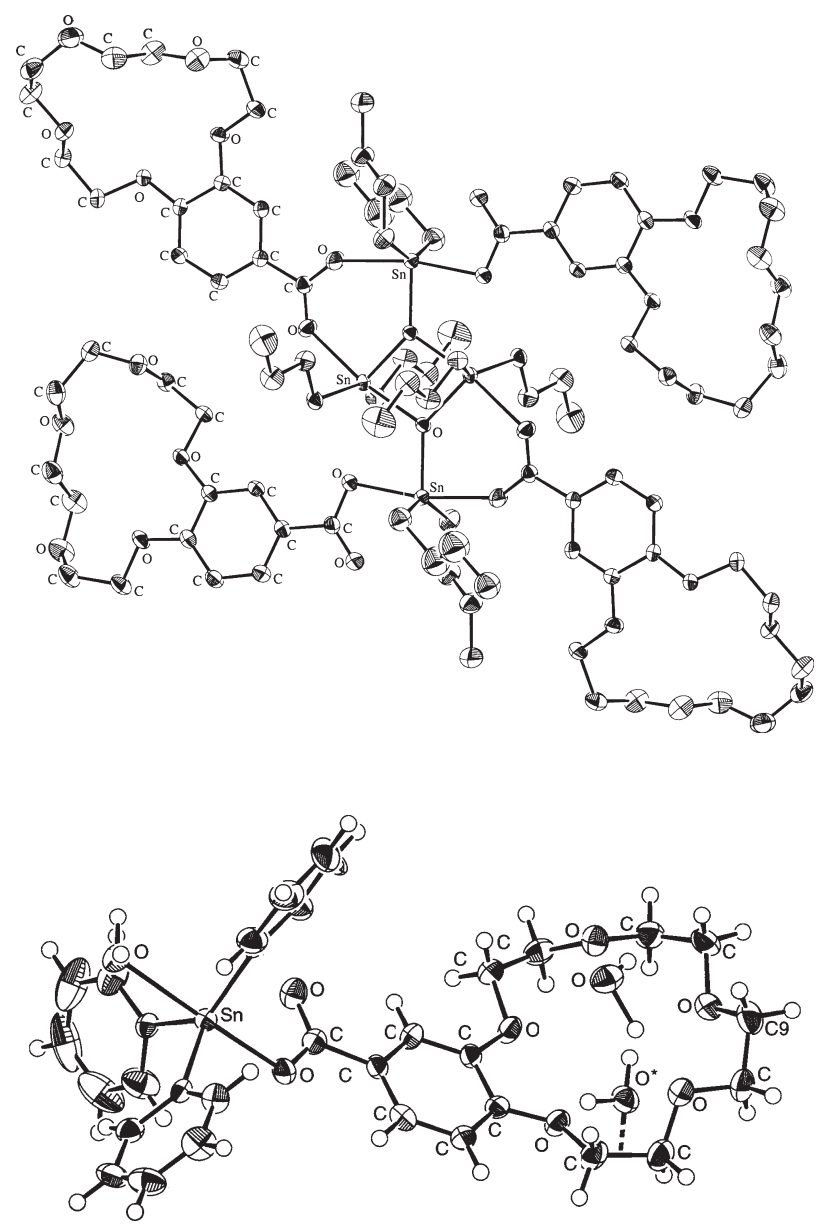

Scheme 19. Crystal structures of compounds 12 and 13.

Some of the polyoxaalkyltin compounds tested, two distannoxanes and two triorganotin derivatives, compounds 4, 8, 13 and 14, are exceptionally active in vitro.

The organotin crownether derivatives exhibit quite interesting chemical properties. Their tin atom is electrophilic because tin, being an element of the fifth period, has got available d-orbitals. It can therefore become five-, six- or seven-coordinate; furthermore, the crown ether cavity has a great affinity for alkaline metals. Such compounds are heterotopic anion-cation sensors because they can easily react with, for instance, sodium thiocyanate, yielding adducts in which the cation is trapped by the crown ether moiety and the anion, linked covalently to tin, ${ }^{39}$ as shown in Scheme 20: 
Table 1. $\mathrm{ID}_{50}$ values $(\mathrm{ng} / \mathrm{mL})$ of organotin polyoxaalkylcarboxylates and of three clinically used drugs, doxorubicin (DOX), methotrexate (MTX) and cisplatin (CPT) tested against seven human tumour cell lines, two mammary cancers, (MCF-7, EVSA-T), a colon carcinoma (WiDr), an ovarian cancer (IGROV), a melanoma (M19 MEL), a renal cancer (A 498) and a non-small cell lung cancer (H1226)

\begin{tabular}{|c|c|c|c|c|c|c|c|}
\hline & MCF-7 & EVSA-T & WiDr & IGROV & M19 MEL & A 498 & $\mathrm{H} 226$ \\
\hline 1 & 27 & 25 & 70 & 77 & 64 & 66 & 68 \\
\hline 2 & 74 & 93 & 190 & 190 & 200 & 350 & 141 \\
\hline 3 & 120 & 124 & 760 & 260 & 230 & 270 & 320 \\
\hline 4 & $<1$ & $<1$ & 3.9 & $<1$ & $<1$ & $<1$ & 3.3 \\
\hline 5 & 17 & 17 & 36 & 63 & 46 & 40 & 47 \\
\hline 6 & 76 & 53 & 84 & 187 & 160 & 200 & 118 \\
\hline 7 & 147 & 112 & 840 & 300 & 280 & 250 & 480 \\
\hline 8 & $<1$ & $<1$ & $<1.8$ & $<1$ & $<1$ & $<1$ & $<1$ \\
\hline 9 & 21 & 17 & 18 & 43 & 23 & 61 & 52 \\
\hline 10 & 53 & 9 & 17 & 45 & 106 & 150 & 150 \\
\hline 11 & 160 & 136 & 830 & 280 & 230 & 300 & 300 \\
\hline 12 & 15 & 19 & 100 & 34 & 29 & 53 & 31 \\
\hline 13 & 2.9 & $<2$ & $<2$ & $<2$ & $<2$ & $<2$ & $<2$ \\
\hline 14 & 3.3 & $<2$ & $<2$ & $<2$ & $<2$ & $<2$ & $<2$ \\
\hline 15 & 320 & 280 & 390 & 380 & 330 & 57 & 580 \\
\hline DOX & 10 & 8 & 11 & 60 & 16 & 90 & 199 \\
\hline MTX & 18 & 5 & $<3$ & 7 & 23 & 37 & 2287 \\
\hline CPT & 699 & 422 & 967 & 169 & 558 & 2253 & 3269 \\
\hline
\end{tabular}

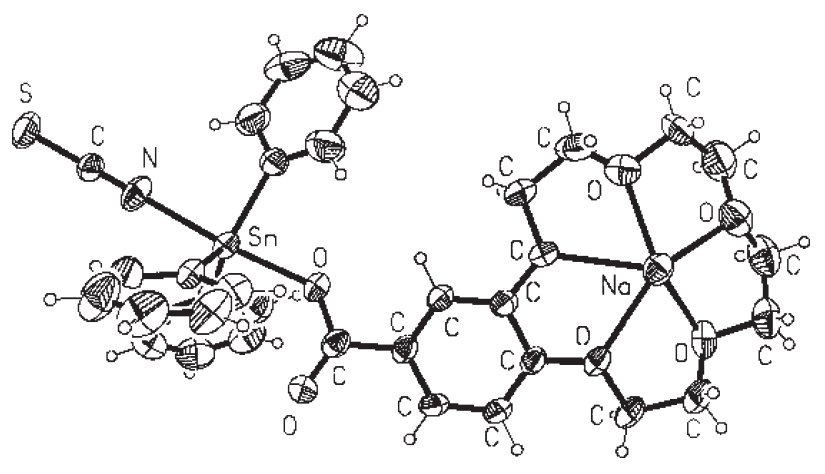

Scheme 20. Adduct of sodium thiocyanate and $\mathbf{1 3}$.

\section{Mode of Action of Antitumour-Active Organotin Compounds}

The platinum compounds used as antitumour drugs have been intensively studied: they interact with DNA and inhibit the cell division. ${ }^{40}$

The interactions of diethyltin dichloride and of watersoluble tri- or diorganotin polyoxaalkanecarboxylates with DNA (fragments) was recently undertaken. ${ }^{41,42}$

Around $\mathrm{pH}$ 7, almost no interaction is detected.

The target of in vitro antitumour-active organotin compounds is being investigated.

\section{Conclusions}

This overview shows that organotin chemistry is a topic where basic and applied chemistry can be done. The mechanism of the cleavage of carbon-tin bonds can serve as model for analogous reactions with other organometallic compounds. The optical stability and stereochemistry at the metal is also a fundamental aspect of these reactions. Furthermore, the antitumour properties of organotin compounds are one of the possible applications of organotin compounds that are already used for instance as catalysts in organic reactions.

\section{References}

1. Gielen, M.; Nasielski, J.; Bull. Soc. Chim. Belg. 1962, 71, 32.

2. Gielen, M.; Nasielski, J.; Bull. Soc. Chim. Belg. 1962, 71, 601.

3. Boué, S; Gielen, M.; Nasielski, J.; J. Organomet. Chem. 1967, 9, 443.

4. Boué, S; Gielen, M.; Nasielski, J.; J. Organomet. Chem. 1967, 9, 461.

5. Gielen, M.; Accounts Chem. Res. 1973, 6, 198.

6. Brocas, J.; Gielen, M.; Willem, R. ; The Permutational Approach to Dynamic Stereochemistry, Mc Graw Hill: New York, 1983.

7. Brown, H. C.; Lane, C. F.; J. Chem. Soc. Chem. Comm. 1971, 521.

8. Gielen, M.; Boué, S.; De Clercq, M.; De Poorter, B.; Rev. Si, Ge, Sn, Pb 1974, 1, 97.

9. Gielen, M.; Fosty, R.; Bull. Soc..Chim. Belg 1974., 83, 333.

10. Boué, S; Gielen, M.; Nasielski, J.; Tetrahedron Lett. 1968, 1047.

11. Gielen, M.; Nasielski, J.; Rec. Trav. Chim. Pays-Bas 1963, 82, 228. 
12. Gielen, M.; Nasielski; Topart, J.; Recl. Trav. Chim. Pays-Bas 1968, 87, 1051

13. Boué, S.; Gielen, M.; Nasielski, J.; Lieutenant, J. P.; Spielmann, R.; Bull. Soc. Chim. Belg. 1969, 78, 135.

14. Gielen, M.; De Poorter, B.; Sciot, M. T.; Topart, J.; Bull. Soc. Chim. Belg. 1973, 82, 271.

15. Gielen, M.; Mokhtar-Jamaï, H.; Bull. Soc. Chim. Belg. 1975, 84, 197.

16. Gielen, M.; Mokhtar-Jamaï, H.; Annals New-York Acad. Sci. 1974, 239, 208.

17. Gielen, M. In Topics in Inorganic and Organometallic Stereochemistry; Geoffroy, G. L., ed., Interscience/John Wiley: New York, 1980, vol. 12, ch. 5, pp. 217-251.

18. Gielen, M. ; Top. Curr. Chem. 1982, 104, 57.

19. Vanden Eynde, I.; Gielen, M.; Stühler, G.; Mannschreck, A.; Polyhedron 1982, 1, 1.

20. Gielen, M.; Vanden Eynde, I.; J. Organomet. Chem. 1980, 198, C55.

21. Gielen, M.; Mokhtar-Jamaï, H.; Bull. Soc. Chim. Belg. 1975 , 84, 1037.

22. Gielen, M.; Mokhtar-Jamaï, H.; J. Organomet. Chem. 1975, 91, C35.

23. Folli, U.; Iarossi, D.;Taddei, F.; J. Chem. Soc., Perkin Trans 2 1973, 1284.

24. Gielen, M.; Tondeur, Y.; J. Organomet. Chem. 1979, 169, 265.

25. Gielen, M.; Pure Appl. Chem. 1980, 52, 657.

26. Gielen, M.; Y. Tondeur, Y. ; J. Organomet. Chem. 1977, 127, C75.

27. Gielen, M.; Tondeur, Y.; J. Organomet. Chem. 1975, 128, $\mathrm{C} 25$.

28. Gielen, M.; Tondeur, Y.; J. Chem. Soc., Chem. Commun. 1978, 81.
29. Gielen, M.; Hoogzand, C.; Vanden Eynde, I.; Bull. Soc. Chim. Belg. 1975, 84, 933.

30. Gielen, M.; Simon, S.; Tondeur, Y.; Van de Steen, M.; Hoogzand, C.; Bull. Soc. Chim. Belg. 1974, 83, 337.

31. Gielen, M.; Vanden Eynde, I.; Israel J. Chem. 1980, 20, 93.

32. Gielen, M.; Vanden Eynde, I.; Transition Met. Chem. 1981, 6, 128.

33. Gielen, M.; Vanden Eynde, I.; Transition Met. Chem. 1981, 6, 344.

34. Gielen, M.; Vanden Eynde, I.; J. Organomet. Chem. 1981, 217, 205.

35. Gielen, M.; Appl. Organomet. Chem. 2002, 16, 481.

36. Gielen, M.; Willem R, Bouhdid A., de Vos D., Pharmachemie B.V.; Eur. Pat. Publ. 700 921, 1996, Appl. 94/202,612.1, 09/ 09/94, (CA 124: 343674z)

37. Kemmer, M.; Biesemans, M.; Gielen, M.; Tiekink, E. R. T.; Willem, R.; J. Organomet. Chem. 2001, 634, 55.

38. Kemmer, M.; Ghys, L.; Gielen, M.; Biesemans, M.; Tiekink, E. R. T.; Willem, R.; J. Organomet. Chem. 1999, 582, 195.

39. Gielen, M.; Willem, R.; Biesemans, M.; Kemmer, M.; de Vos, D., Pharmachemie B.V., World Pat. Publ. C07F 7/22, A61K 31/32 Nr. WO 00/06583, 2000, Appl. PCT/NL98/00429, 28/ 7/98, Publ. 10/02/00 (CA 132:132333q).

40. Stone, P. J.; Kelman, A. D.; Sinex, F. M.; Nature 1974, 251, 736.

41. Kemmer M.; Biesemans M.; Gielen M.; Martins, J. C.; Gramlich,V.; Willem, R.; Chem. Eur. J. 2001, 7, 4686.

42. Casini, A.; Messori, L.; Orioli, P.; Gielen, M.; Kemmer, M.; Willem, R.; J. Inorg. Biochem. 2001, 85, 297.

43. Ghys, L; Biesemans, M.; Gielen, M.; Garoufis, A; Hadjiliadis, N.; Willem, R.; Martins, J. C.; Eur. J. Inorg. Chem. 2000, 513.

Received: October 18, 2002 Published on the web: December 4, 2003 